Original Article

\title{
THE IMPACT OF ANTIRETROVIRAL THERAPY ON HEMOGLOBIN LEVELS OF HIV/AIDS PATIENTS AT MERPATI CLINIC, WANGAYA HOSPITAL, DENPASAR, BALI, INDONESIA
}

\author{
PUTU DEWINTA DARMADA', KETUT SURYANA²
}

${ }^{1}$ General Practitioner, Wangaya General Hospital in Denpasar, Bali, Indonesia, ${ }^{2}$ Department of Internal Medicine, Wangaya HIV Study Group, Merpati Clinic, Wangaya General Hospital, Denpasar, Bali, Indonesia

Email: dewinta29@gmail.com

Received: 11 Jun 2020, Revised and Accepted: 13 Jul 2020

\begin{abstract}
Objective: Anemia is responsible for poor outcomes in HIV/AIDS patients. It's related to disease progression, morbidity, and mortality. Antiretroviral therapy (ART) agent, zidovudine (ZDV) is also known to trigger anemia in the early initiation. However, studies found improved hemoglobin $(\mathrm{Hb})$ levels of HIV/AIDS patients several months after ART routinely taken. This study aims to find the impact and correlation of ART on the hemoglobin level of HIV/AIDS patients.
\end{abstract}

Methods: A retrospective cohort study was done at Merpati Clinic, Wangaya Hospital, Denpasar-Bali, Indonesia. Data were collected from medical records and laboratory results. A total sample of 64 HIV/AIDS patients with at least 6 mo on ART was included in this study.

Results: Anemia was found in $34(53.1 \%)$ of patients before ART initiation. After taking ART for 6 mo, we observed a significant improvement in patients' hemoglobin levels, $48(75 \%)$ shows increased hemoglobin levels. The paired t-test revealed a correlation between ART and Hb level $(\mathrm{p}<0.001)$. Fourteen $(43.8 \%)$ patient taking ZDV shows no improvement, even declining of Hb level. Chi-square analysis performed with $\mathrm{p}=0.001$ to ZDV and lower or no improvement of hemoglobin level. Both results considered statistically significant (p-value less than 0.05) with a confidence interval (CI) of 95\%. Relative risk (RR) of no improvement or decline in Hb level is 7 folds higher in the ZDV group than the non-ZDV group.

Conclusion: This study concludes that ART affects hemoglobin levels in HIV/AIDS patients. Zidovudine regimen is more prone to lower or no increase of $\mathrm{Hb}$.

Keywords: Antiretroviral therapy, Anemia, Hemoglobin, HIV/AIDS

C 2020 The Authors. Published by Innovare Academic Sciences Pvt Ltd. This is an open access article under the CC BY license (http://creativecommons.org/licenses/by/4.0/) DOI: http://dx.doi.org/10.22159/ijpps.2020v12i9.38721. Journal homepage: https://innovareacademics.in/journals/index.php/ijpps.

\section{INTRODUCTION}

Anemia is considered as a frequently found hematological problem affecting more than one-third of HIV patients [1,2]. Previous researches have reported that the prevalence of anemia in HIV naïve patients varies between $25.8-34.6 \%$ [2-4]. However, other studies found a higher prevalence of anemia in $71-86.4 \%$ of HIV/AIDS patients. Anemia in HIV patients correlates strongly to disease progression, morbidity, and mortality. Routine screening of anemia should be done and anemia should be properly addressed in HIV patients [5-7].

Human Immunodeficiency Virus is known to lead inflammatory cytokines discharge, erythropoiesis disturbance, depletion of hematopoietic growth factors, with malabsorption and ineffective iron recycling and eventually causing anemia $[3,6]$. Several drugs in the standard regiment of Antiretroviral Therapy (ART) such as zidovudine (ZDV) affect hematopoiesis, thus contributes to anemia. The decrease of CD4 counts also strongly associated with the severity of anemia $[8,9]$. Anemia can be classified into a few groups, based on the severity (mild, moderate, and severe anemia). Mild anemia is described as a hemoglobin level of 11-11.9 g/dl. Moderate anemia is when the hemoglobin level $8-10.9 \mathrm{~g} / \mathrm{dl}$. The diagnosis of severe anemia is made if the hemoglobin level is $<8 \mathrm{~g} / \mathrm{dl}[7,10]$.

Antiretroviral therapy (ART) should be initiated as soon as the diagnosis of HIV infection was made. This early administration of ART aims to suppress the viral load, restore the immune system, and improve the clinical outcome in HIV patients. From a medical perspective, ART has turned the HIV diagnosis to chronic disease instead of terminal disease $[9,11]$. Yesuf T et al. reported that ART initiation reduces the prevalence of anemia in HIV patients after 6 mo and 12 mo [1]. The same result also comes from another study in Ethiopia. They found that after 6 mo of ART initiation, the hemoglobin level increased significantly [7]. Another study reported that ZDV triggers anemia in HIV patients, especially 1 to 3 mo after initiation. Tamir et al., compared anemia on two groups of HIV patients. The first group is taking non-zidovudine ART and second group on ART with zidovudine. It was later found that there was a higher risk of anemia in the zidovudine group [12]. More researches should be done to establish a clear role of ART in anemic HIV patients. This study aims to find the impact of ART on the hemoglobin level of HIV patients visiting Merpati Clinic, Wangaya Hospital, Denpasar-Bali, Indonesia.

\section{MATERIALS AND METHODS}

Research design

A retrospective cohort study was done in May 2020 at Merpati Clinic, Wangaya Hospital, Denpasar, Bali, Indonesia. The data for this study were collected from the patients' medical records. This study was granted an ethical clearance: 02/RSUDW/litbang/2020 from local Ethical Committee.

\section{Population and sample of the study}

The study was held at Merpati Clinic, Wangaya Hospital, Denpasar, Bali, Indonesia in May 2020. Consecutive sampling was done, and we obtained a total of $64 \mathrm{HIV} /$ AIDS patients as participants. All of the participants of this study fulfilled the inclusion and exclusion criteria. The inclusion criteria are HIV/AIDS patients with the age of $18 \mathrm{y}$ old and above, with minimum Antiretroviral therapy duration of 6 mo with a complete medical record. Pregnant and lactating women, patients with chronic renal disease, and patients with thalassemia were excluded from this study.

\section{Variables and data sources}

Beside demographic characteristic (age, sex, weight, education, marital status), variables used on this study are; HIV/AIDS staging, 
types of anemia: mild (Hb level 11-11.9 d/dl), moderate (Hb level 8$10.9 \mathrm{~d} / \mathrm{dl}$ ), severe $(\mathrm{Hb}$ level<9 g/dl); hemoglobin level (before ART initiation and after ART initiation), types of regimen taken: tenofovir+lamivudine+efavirenz (Fixed Drug Combination/FDC or TDF/3TC/EFV), tenofovir+lamivudine+nevirapine (TDF/3TC/NVP) zidovudine+lamivudine+efavirenz (ZDV/3TC/EFV), and zidovudine+ lamivudine+nevirapine (ZDV/3TC/NVP). Included also: CD4+level of $<200$ or $\geq 200$ : and opportunistic infection. We collected patient's data from the medical record.

\section{Data analysis}

Patients' hemoglobin and ART initiation data were taken from the medical record and the laboratory result of the hematologic panel. The hemoglobin levels of the patient before starting ART and after taking ART for 6 mo were compared. Demographic characteristics such as gender, age, CD4 count, the severity of anemia, opportunistic infection, and regimen. The association between hemoglobin value before and after ART was analyzed using a paired t-test, while the correlation of zidovudine and lower hemoglobin level after ART were analyzed with the chi-square test. With a p-value of $<0.05$ and a $95 \%$ confidence interval considered statistically significant in both tests.

\section{RESULTS}

\section{Before ART initiation}

As shown in table 1, from 64 HIV/AIDS patients included in this study, the mean age is 43.88 y old, with a standard deviation (SD) of 9.667. The mean weight of the samples is 57.64 kilograms, with an SD of 9.037 . Thirty-five males (54.7\%) and $29(45.3 \%)$ women were included in this study. The overall prevalence of anemia was 34 (53.1\%). Initial Hb level (before ART) mean \pm SD was $11.645 \pm 1.6768$ $\mathrm{g} / \mathrm{dl}$. The CD4 count before ART started divided into two group, 51 (79.7\%) patients with CD $4<200$ cell $/ \mathrm{mm}^{3}$ and $13(20.3 \%)$ patients with $\mathrm{CD} 4 \geq 200 \mathrm{cell} / \mathrm{mm}^{3}$. Seventeen patients $(26.6 \%)$ experienced opportunistic infection, and 62 patients (96.9\%) of the sample were in the HIV stage. The most regimen used is the Fixed Drug Combination (TDF/3TC/EFV) of tenofovir, lamivudine, and efavirenz, account to $27(42.2 \%)$ of the patients, followed by zidovudine, lamivudine, and nevirapine regimen (ZDV/3TC/NVP) taken by 22 (34.4\%) patients.

\section{After ART initiation}

We found $48(75 \%)$ of the patient shows improvement in hemoglobin levels. The other $16(25 \%)$ didn't show improved hemoglobin levels or even decreased. The mean \pm SD of Hb value after ART is $12.756 \pm 1.7750 \mathrm{~g} / \mathrm{dl}$. Initial hemoglobin value $($ Mean $=$ 11.645, SD = 1.6768) and Hemoglobin value after 6 mo of ART $($ Mean $=12.756, \mathrm{SD}=1.7750)$ were tested using paired t-test. Data on the hemoglobin level was normally distributed from the Kolmogorov-Smirnoff test, and the value of skew and kurtosis were estimated at 0.084 and-0.306, respectively. We also found that the correlation between the condition was estimated at $r=0.350, p=$ 0.005 . This indicates a paired t-test is appropriate to use. From the analysis, it was found that there is a correlation between the initiation of ART and hemoglobin value in HIV patients, with a pvalue $<0.001$ (table 2). Zidovudine containing regimen and risk of anemia (or lower $\mathrm{Hb}$ level) is also observed in table 3 with p-value $=$ 0.001 . Relative risk (RR) of the ZDV group compared to the non-ZDV group is 7 folds higher than in those without the ZDV regimen.

Table 1: Demographic characteristic of the participant before starting ART

\begin{tabular}{|c|c|c|c|}
\hline Variables & n (\%) & mean \pm SD & Median (min, max) \\
\hline Age & & $43.88 \pm 9.667$ & $42(28,68)$ \\
\hline Weight & & $57.64 \pm 9.037$ & $56(40,82)$ \\
\hline $\mathrm{Hb}$ before ART initiation & & $11.645 \pm 1.6768$ & $11.9(8.1,15.1)$ \\
\hline $\mathrm{Hb}$ after ART initiation & & $12.756 \pm 1.7750$ & $12.7(9.0,16.6)$ \\
\hline \multicolumn{4}{|l|}{ Sex } \\
\hline Male & $35(54.7)$ & & \\
\hline Female & $29(45.3)$ & & \\
\hline \multicolumn{4}{|l|}{ Education } \\
\hline Elementary school & $10(15.6)$ & & \\
\hline Junior High School & $9(14.1)$ & & \\
\hline Senior High School & $39(60.9)$ & & \\
\hline University & $6(9.4)$ & & \\
\hline \multicolumn{4}{|l|}{ Marital } \\
\hline Unmarried & $2(3.1)$ & & \\
\hline Married & $49(76.6)$ & & \\
\hline Widowed/Divorced & $13(20.3)$ & & \\
\hline \multicolumn{4}{|l|}{ HIV/AIDS staging } \\
\hline HIV & $62(96.9)$ & & \\
\hline AIDS & $2(3.1)$ & & \\
\hline \multicolumn{4}{|l|}{ ART regimen } \\
\hline $\mathrm{TDF} / 3 \mathrm{TC} / \mathrm{EFV}(\mathrm{FDC})$ & $27(42.2)$ & & \\
\hline TDF/3TC/NVP & $5(7.8)$ & & \\
\hline ZDV/3TC/EFV & $10(15.6)$ & & \\
\hline ZDV/3TC/NVP & $22(34.4)$ & & \\
\hline \multicolumn{4}{|l|}{ Anemia before ART } \\
\hline Yes & $34(53.1)$ & & \\
\hline Mild Anemia & $13(20.3)$ & & \\
\hline Moderate Anemia & $21(32.8)$ & & \\
\hline No & $30(46.9)$ & & \\
\hline \multicolumn{4}{|c|}{ Hb improvement after ART } \\
\hline Yes & $48(75)$ & & \\
\hline No & $16(25)$ & & \\
\hline \multicolumn{4}{|l|}{ CD4+count } \\
\hline$<200 \mathrm{cell} / \mathrm{mm}^{3}$ & $51(79.7)$ & & \\
\hline$\geq 200 \mathrm{cell} / \mathrm{mm}^{3}$ & $13(20.3)$ & & \\
\hline \multicolumn{4}{|l|}{ Opportunistic infection } \\
\hline Yes & $17(26.6)$ & & \\
\hline No & $47(73.4)$ & & \\
\hline
\end{tabular}


Table 2: Mean hemoglobin (Hb) value

\begin{tabular}{lllll}
\hline Variables & Mean \pm SD & \multirow{2}{*}{ Mean difference (95\% CI) } & t-statistic (df) & p-value \\
\cline { 2 - 4 } & Before ART initiation & After ART initiation & & \\
\hline $\begin{array}{l}\text { Hemoglobin } \\
(\mathrm{g} / \mathrm{dl})\end{array}$ & $11.645 \pm 1.6768$ & $12.756 \pm 1.7750$ & $-1.1109(-1.6027,-0.6191)$ & $-4.514(63)$ \\
\hline
\end{tabular}

$\mathrm{n}=64, \mathrm{SD}=$ standard deviation, $\mathrm{CI}=$ confidence interval, $\mathrm{df}=$ degree of freedom, ${ }^{*}$ paired $\mathrm{t}$-test

Table 3: Correlation of ZDV containing ART regimen with hemoglobin (Hb) level

\begin{tabular}{lllll}
\hline Variables & No increase of Hb (\%) & Increase of Hb (\%) & $\mathbf{N}$ & $\boldsymbol{\chi} 2$ statistic (df) \\
\hline ART with ZDV & $14(43.8)$ & $18(56.3)$ & 32 & $12(1)$ \\
ART without ZDV & $2(6.3)$ & $30(93.8)$ & 32 & $0.001^{* *}$ \\
\hline
\end{tabular}

${ }^{* *}$ chi-square, RR (Relative Risk) $=7$

\section{DISCUSSION}

Anemia is dubbed as a marker of disease progression in HIV/AIDS and associated with poor outcomes. The initiation of ART is believed to reverse this condition, marked by an increase in hemoglobin level and associated with better survival (prognosis) [14, 15]. Anemia prevalence in HIV/AIDS patients varies greatly. In this study, we found the prevalence of anemia of $53.1 \%$. Panwar A et al. reported that $86.4 \%$ of HIV patients experience anemia, while other studies found a $38.8 \%$ prevalence of anemia in HIV patients $[6,14]$. Among the anemia prevalence, a study in Ethiopia declares that $84.1 \%$ of HIV patients had mild anemia, and $15.9 \%$ had moderate anemia [7]. While we found about $20.3 \%$ had mild anemia, and $32.8 \%$ had moderate anemia.

Based on the statistical analysis of this study, we found that the mean hemoglobin level increased after the patient taking ART at least for 6 mo. This finding accompanied by the $p$-value of $<0.001$, which shows there was a significant correlation of hemoglobin level and ART. Previous researches also reported similar findings in which ART was found to increase the $\mathrm{Hb}$ level of HIV patients $[1,8$ 13]. The mean value of $\mathrm{Hb}$ before ART is $11.645 \pm 1.6768$, and after ART is $12.756 \pm 1.7750$. Similar research conducted by Woldeamanuel GG et al. reported the mean value of $\mathrm{Hb}$ before and after ART was $12.8 \pm 1.99 \mathrm{~g} / \mathrm{dl}$ versus $14.34 \pm 1.89 \mathrm{~g} / \mathrm{dl}$, respectively [7]. Both studies met the same conclusion that ART initiation can improve $\mathrm{Hb}$ levels in HIV patients.

Zidovudine (ZDV/AZT) is found to cause anemia among patients as its adverse effect $[8,9,13,16]$. Three different studies reported that the prevalence of anemia as a side effect of zidovudine therapy found on $10.6 \%, 34.6 \%$, and anemia after administration of ART regimen (not specified) in $46.15 \%$ patients [17-19]. In this study, we found that $14(43.8 \%)$ patients receiving ZDV based regimen didn't show improvement of $\mathrm{Hb}$ level. These patients' $\mathrm{Hb}$ levels even reduced. Statistical significance of $\mathrm{p}$-value $=0.001$ which shows there's an association between ZDV takers and no increase of $\mathrm{Hb}$ level or lower in $\mathrm{Hb}$ level. Patients taking zidovudine containing regimens are also developing a risk of no increase of $\mathrm{Hb}$ or lower $\mathrm{Hb}$ level by 7 times more than the non-zidovudine group. Tamir $\mathrm{Z}$ et al., also reported that the patients taking regimen with zidovudine are in 3.34 folds risk than patients taking non-zidovudine ART [11] Therefore, routine screening of anemia in patients with ART treatment is important, especially for the regimen with zidovudine.

\section{CONCLUSION}

Anemia in HIV/AIDS patients is constituted by many factors, including the disease itself and side effects of the regimen of medication. Antiretroviral therapy (ART) initiation in HIV patients can lead to the improvement of hemoglobin levels, especially after 6 mo. However, a regimen containing zidovudine had more risk to develop anemia or a decrease in $\mathrm{Hb}$ level. Routine hematologic panel monitoring, especially for anemia $(\mathrm{Hb})$ should be done, even in patients without symptoms, because it's related to the disease progression and patient's prognosis. Other causes of anemia must be sought and excluded before treating the patients and regimen change should be considered in patients with anemia.

\section{STUDY LIMITATION}

The limitation of this study was the small sample size.

\section{ACKNOWLEDGEMENT}

The authors express gratitude to the Director of Wangaya Hospital, Denpasar, Bali, Indonesia, and all colleagues of Wangaya HIV Study Group. Special thanks to Puji Astuti, Putri Stuti, and Yuliawati, who have supported this study.

\section{FUNDING}

Nil

\section{AUTHORS CONTRIBUTIONS}

Putu Dewinta Darmada contributes to research planning, data collection and data management, logical interpretation of the results, literature review, and construction of the manuscript. Ketut Suryana contributes to research planning, idea construction, supervising the course of the project and research article, logical interpretation of the result, reviewing and approving the article before submission.

\section{CONFLICT OF INTERESTS}

The authors reported there was no conflict of interest in this study.

\section{REFERENCES}

1. Yesuf T, Muhie OA, Shibru H. Prevalence and predictors of anemia among adult HIV infected patients at the University of gondar hospital, Northwest Ethiopia. HIV AIDS (Auckl) 2019;11:211-7.

2. Gebremedhin KB, Haye TB. Factors associated with anemia among people living with HIV/AIDS taking ART in Ethiopia. Adv Hematol 2019;2:1-8.

3. Takuva S, Maskew M, Brennan AT, Sanne I, MacPhail AP, Fox MP. Anemia among HIV-infected patients initiating antiretroviral therapy in South Africa: Improvement in hemoglobin regardless of degree of immunosuppression and the initiating ART regimen. J Trop Med 2013;1-6.

4. Ferede G, Wondimeneh Y. Prevalence and related factors of anemia in HAART-naive HIV positive patients at Gondar University Hospital, Northwest Ethiopia. BMC Blood Disord 2013;13:8.

5. Meidani M, Rezaei F, Maracy MR, Avijgan M, Tayeri K. Prevalence, severity, and related factors of anemia in HIV/AIDS patients. J Res Med Sci 2012;17:138-42.

6. Panwar A, Sharma SC, Kumar S, Sharm A. A study of anemia in human immunodeficiency virus patients: Estimating the prevalence, analyzing the causative effect of nutritional deficiencies, and correlating the degree of severity with CD4 cell counts. Med J DY Patil Univ 2016;9:312-8.

7. Woldeamanuel GG, Wondimu DH. Prevalence of anemia before and after initiation of antiretroviral therapy among HIV infected patients at Black Lion Specialized Hospital, Addis Ababa, Ethiopia: a cross sectional study. BMC Hematol 2018;18:7. 
8. Redig AJ, Berliner N. Pathogenesis and clinical implications of HIV-related anemia in 2013. Hematology Am Soc Hematol Educ Program 2013;1:377-81.

9. Saag MS, Benson CA, Gandhi RT, Hoy JF, Landovitz RJ, Mugavero MJ, et al. Antiretroviral drugs for treatment and prevention of HIV infection in adults. JAMA 2018;320:379-96.

10. World Health Organization. Worldwide prevalence on anaemia 1993-2005. Geneva: World Health Organization; 2008. p. 4-6.

11. Limmade Y, Fransisca L, Rodriguez Fernandez R, Bangs MJ, Rothe C. HIV treatment outcomes following antiretroviral therapy initiation and monitoring: a workplace program in Papua, Indonesia. PLoS One 2019;14:e0212432.

12. Tamir Z, Alemu J, Tsegaye A. Anemia among HIV infected individuals taking ART with and without zidovudine at Addis Ababa, Ethiopia. Ethiop J Health Sci 2018;28:73-82.

13. Johannessen A, Naman E, Gundersen SG, Bruun JN. Antiretroviral treatment reverses HIV-associated anemia in rural Tanzania. BMC Infectious Diseases 2011;11:190.

14. Wahyuwibowo J, Harumsari S, Zulaikha ST, Suwondo A, Sofro MAU, Hadisaputro S. Age and CD4 count are dominant factors in the prediction of anaemia in Javanese HIV patients. Asia Pac J Clin Nutr 2018;27:649-54.

15. De Santis G, Brunetta D, Vilar F, Brandao R, de Albernaz Muniz $\mathrm{R}$, de Lima $\mathrm{G}$, et al. Hematological abnormalities in HIV-infected patients. Int J Infect Dis 2011;15:e808-11.

16. Insaniputri $P$, Supardi $S$, Andrajati R. Comparison of zidovudine combination and tenofovir combination on the effectiveness of therapy and side effects in HIV/AIDS patients in RSAL mintohardjo. Asian J Pharm Clin Res 2017;10 Suppl 5:93-6.

17. Chioma AD, Chukwuma B, Chinomnso C. Prevalence and pattern of adverse drug reactions among HIV infected patients on highly active antiretroviral therapy (HAART) in Imo State, Nigeria: a hospital based survey. J Drug Delivery Ther 2019;9 Suppl 6s:5-11.

18. Bansal R, Daryani KK, Singh AP. Pharmacovigilance study of antiretroviral therapy in human immunodeficiency virus/acquired immunodeficiency syndrome patients at the antiretroviral therapy centre, Jabalpur. Asian J Pharm Clin Res 2018;11:272-9.

19. Hiremath RN, Patil SS, Yadav AK. Nutritional status of people living with HIV/acquired immunodeficiency syndrome-a crosssectional study. Asian J Pharm Clin Res 2018;11:456-9. 